\title{
Cooperative Acquisitions
}

W

HAT IS MEANT by the phrase "cooperative acquisitions?" You remember that it was said of a noted eighteenth-century preacher that he could pronounce the single word "Mesopotamia" in such a fashion as to make his audience either weep or laugh. I do not think that the phrase "cooperative acquisitions" has actually achieved the versatility of "Mesopotamia," but I believe you will agree that it has acquired a great number of connotations, some very noble and some not too happy. The phrase has a dual meaning in that it can be applied either to programs of joint or cooperative purchasing, or to programs in which joint purchasing is by no means an essential feature, the objective of which is to avoid duplication or to increase total resources. It is in the latter sense that we use the phrase today. However, there are still other fringes of meaning or connotation. Over the years, cooperative acquisition has been regarded by librarians as a sort of ultimate in efficiency for certain purposes, which, if it could only be realized, should be wholeheartedly embraced and would ennoble the participants. The diffculties to its realization, however, have been great; and, because they include a degree of self-discipline on the part of libraries in the general good, the phrase "cooperative acquisitions" has become tinctured with connotations of self-denial-of abstention from buying what you want, but instead of buying perhaps something you want less; of loss of flexibility and adaptability in acquisi-

${ }^{1}$ Comments presented at the Conference of Eastern College Librarians, Columbia University, Nov. 30, r 946 . tion operations through being enchained within the meshes of a system; in fact, of a general loss of individual freedom. Consequently, even bilateral acquisition agreements between libraries have not always been completely honored; and, although general programs have been under discussion in this country for many years, no general program has as yet been worked out in practicable detail.

At the end of the First World War, American librarians, assessing their experience during the war, came to the conclusion that our library resources had been neither adequate in themselves nor adequately mobilized to the demands which had been made upon them, let alone the demand which might have been made upon them had they been able to respond.

We now stand at the end of a Second World War, and we have generally, I think, rendered the same judgment that was rendered after 1918. Yet we have come a long way in the interim in the direction of improving and mobilizing our resources of library materials.

You know of the successful interlibrary arrangements made in Nashville, Philadelphia, Denver, Ohio, North Carolina, Pacific Northwest, and other places, sometimes involving the establishment of a regional union catalog, but not necessarily doing this. You know of the development not only of regional union catalogs but of the national union catalog. The Union List of Serials and other union lists have been published, serving an enormously successful role in making our materials known and 
accessible. The extension and codification of interlibrary loans, the development of microfilm services, have played an important part. Meanwhile, also, studies of specialization of collections continued up to our entry into the last World War in many discussions and publications, without, however, resulting in any generally acceptable plan for application of the specialization principle to the over-all picture.

This is still, substantially, the situation. However, this time, we did not have to wait for the end of the war to come to the conclusion that through cooperation only, will we not only record, but even acquire the materials which, as a country, we need. We now have before us a concrete and specific proposal for the form which such cooperation may take. This is the so-called Farmington, or Boyd-MacLeish-Metcalf, plan, projected by the librarians of Princeton, Congress, and Harvard, in 1942. At least we are in this position now-if we have to be convinced by coming through a war that cooperation is valuable, needful, or essential, at least we now have a proposal on which to act before our conviction fades. I do not believe, however, that our conviction will be allowed to fade, but that, on the contrary, our users will continue as during the war to make demands upon us which we cannot meet until we are forced in desperation to do something.

Meanwhile, as a sort of precursor of a general plan, there has been developed a special project which has had as its object the procurement and distribution of recent European library materials. The paper by Reuben Peiss, included on pages II3-19, discusses this project.

It has been felt desirable that we provide papers on planned cooperative acquisition in the interest of national resources by two librarians who are also scholars in particular subject fields. The first of these, who represents the point of view of the library of a large university, is Julian P. Boyd, the librarian of Princeton, one of the coauthors of the Farmington plan, and wellknown for his work in American history. The other paper which may be said to represent the college library is by Dean Lockwood, professor of Latin and librarian at Haverford. The paper by Dr. Boyd is printed on pages IOI-09, and that by Professor Lockwood on pages IIO-I2. 